\title{
Methodological path to reach the degree of saturation in qualitative research: grounded theory
}

\author{
Percurso metodológico para alcance do grau de saturação na pesquisa qualitativa: teoria fundamentada
}

Marco metodológico para alcance del grado de saturación en la investigación cualitativa: teoría fundamentada

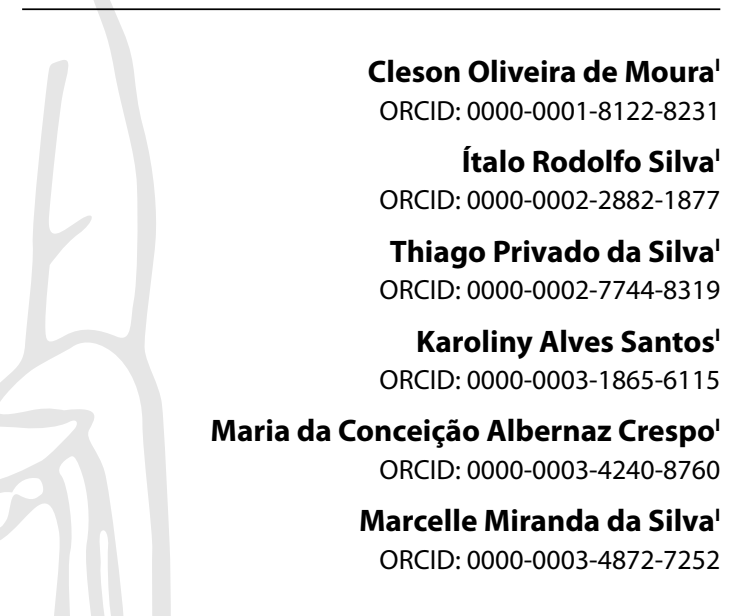

'Universidade Federal do Rio de Janeiro. Rio de Janeiro, Rio de Janeiro, Brazil.

How to cite this article: Moura CO, Silva IR, Silva TP, Santos KA, Crespo MCA, Silva MM. Methodological path to reach the degree of saturation in qualitative research: grounded theory. Rev Bras Enferm. 2022;75(2):e20201379. https://doi.org/10.1590/0034-7167-2020-1379

\section{Corresponding author: Marcelle Miranda da Silva E-mail:marcellemsufrj@gmail.com}

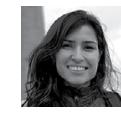

EDITOR IN CHIEF: Antonio José de Almeida Filho ASSOCIATE EDITOR: Ana Fátima Fernandes

Submission: 01-13-2021

Approval: 04-11-2021

\begin{abstract}
Objectives: to achieve the degree of saturation in study that applied the grounded theory. Methods: qualitative research, carried out in four Family Health Units, between June 2018 and May 2019. The data from the interviews with 30 health professionals and non-participant observation were coded in the stages: open, axial and integration. Results: the degree of saturation was achieved by two conceptual models - theoretical saturation and inductive thematic. Theoretical saturation was considered: the development of conceptual codes and observation, in the collection and analysis of data, when they generated new categories/ subcategories or only indicated increasing instances. For thematic inductive saturation, the use of new codes based on each interview stood out. Final Considerations: the visual layout for the number of codes, the theoretical scope of the concepts and the delimitation of the sample groups guided the identification of the degree of saturation for the development of the conceptual body that supported the substantive theory.

Descriptors: Methods; Qualitative Research; Grounded Theory; Data Collection; Nursing Research.
\end{abstract}

\section{RESUMO}

Objetivos: alcançar o grau de saturação em estudo que aplicou a teoria fundamentada. Métodos: pesquisa qualitativa, realizada em quatro Unidades Saúde da Família, entre junho de 2018 e maio de 2019. Os dados das entrevistas com 30 profissionais de saúde e observação não participante foram codificados nas etapas: aberta, axial e integração. Resultados: o grau de saturação foi alcançado por dois modelos conceituais - saturação teórica e temática indutiva. Foram considerados para a saturação teórica: o desenvolvimento dos códigos conceituais e a observação, na coleta e análise dos dados, quando geravam novas categorias/subcategorias ou apenas indicavam instâncias crescentes. Para a saturação temática indutiva, destacou-se a utilização de novos códigos baseados em cada entrevista. Considerações Finais: a esquematização visual para a quantidade de códigos, abrangência teórica dos conceitos e delimitação dos grupos amostrais orientou a identificação do grau de saturação para o desenvolvimento do corpo conceitual que sustentou a teoria substantiva. Descritores: Métodos; Pesquisa Qualitativa; Teoria Fundamentada; Coleta de Dados; Pesquisa em Enfermagem.

\section{RESUMEN}

Objetivos: alcanzar grado de saturación en estudio que aplicó la teoría fundamentada. Métodos: investigación cualitativa, realizada en cuatro Unidades Salud de la Familia, entre junio de 2018 y mayo de 2019. Datos de entrevistas con 30 profesionales de salud y observación no participante fueron codificados en las etapas: abierta, axial e integración. Resultados: grado de saturación fue alcanzado por dos modelos conceptuales - saturación teórica y temática inductiva. Fueron considerados para la saturación teórica: el desarrollo de códigos conceptuales y observación, en la recolecta y análisis de los datos, cuando generaban nuevas categorías/subcategorías o apenas indicaban instancias crecientes. Para la saturación temática inductiva, destacó la utilización de nuevos códigos basados en cada entrevista. Consideraciones Finales: la esquematización visual para la cantidad de códigos, inclusión teórica de los conceptos y delimitación de los grupos muestrales orientó la identificación del grado de saturación al desarrollo del cuerpo conceptual que sustentó la teoría sustantiva. Descriptores: Métodos; Investigación Cualitativa; Teoría Fundamentada; Recolección de Datos; Investigación en Enfermería. 


\section{INTRODUCTION}

The construction of scientific knowledge in nursing has in qualitative research a possibility to prove and prove that, in addition to cause and effect relationships, it is necessary to know the meanings attributed to social experiences, because, as a profession, nursing experiences different phenomena that go beyond the question of biological issues ${ }^{(1)}$.

Qualitative research that uses grounded theory (GT) as a methodological or theoretical-methodological framework, also known in Brazil as "teoria fundamentada nos dados" (GT), aims to understand the meaning of an object of study for people who share experiences and interact in a specific social context. Such understanding is allowed by the development of concepts, hypotheses and theories that emerge from the empirical data through a set of systematic procedures for comparative analysis of the data. The method offers the possibility of exploring a certain phenomenon and its dynamics, in the context in which it occurs ${ }^{(1-5)}$.

Studies highlight GT as a method to be used in qualitative research, in health sciences, being one of the most used in nursing, which allows unveiling social issues, such as injustices that affect the well-being of groups marginalized by society; in addition, it enables a new view of nursing knowledge and practices, in line with the needs of the population and the Unified Health System (SUS) $)^{(6-8)}$.

Regardless of the methodological perspective of the GT (such as the classic, Straussian or constructivist), the rigor in the application of the method requires the researcher, in addition to the theoretical knowledge of its elements, reflections and decisions that allow to advance in the research to unveil the phenomenon, carefully following the methodological path amid the diversity of paths and possibilities to be followed ${ }^{(2-4,9)}$.

Along this path, certainties and uncertainties may arise regarding the moment of data collection and analysis when the degree of saturation is reached, especially in studies that intend to develop a substantive theory, applied to the investigated field.

To reach the degree of saturation, the researcher must identify concepts, develop them, and relate them. Theoretical depth is fundamental in the abstraction and delimitation necessary to the scope that these concepts involved in understanding reality. From this conjuncture, it is possible to understand the importance of the researcher to know the methodological elements that involve saturation in order to then be able to identify when the concepts, which can be translated into categories and subcategories, are already sufficiently capable of covering the research phenomenon.

As a methodological principle originated in GT and widely accepted in other qualitative methods, saturation indicates, based on the data collected and analyzed, that it is not necessary to proceed with the collection of new data ${ }^{(10-11)}$. At GT, behavioral patterns are coded until saturation is reached, when the process is interrupted since the incident data do not generate new properties or dimensions for the categories and the developed conceptual body $\mathbf{y}^{(6,12)}$.

There are four conceptual models of saturation described in the literature, three of which are related to GT, namely: theoretical saturation, inductive thematic saturation and a priori thematic saturation. The first concerns the degree of development of the categories already developed, seeking, through theoretical sampling, to saturate the identified codes. The second refers to the emergence of new codes and not to the degree of development of those already identified, based, then, on the number of codes, centered on the level of analysis. The third is guided by the existence of sufficient data to illustrate the developed theory and its adequacy in a more comprehensive way, and not specifically given to data, receiving in its nomenclature the term "a priori" for pointing to the idea of predetermined theoretical categories ${ }^{(10)}$.

The fourth conceptual model, called "data saturation", when outside the context of the GT, is usually linked to the amount of data and number of interviews required until no new topic appears, operating using the data provided by each participant, individually, in a separate perspective of the data analysis process ${ }^{(10)}$.

It is observed that the saturation in the GT can be related to the theoretical sampling and construction of the sample groups, to the analysis of the emergence of new codes, to the theoretical adequacy and to the achievement of the objectives of the study and answer to the guiding questions. However, it is common to observe, in the research reports, inconsistencies and contradictions in the application of the concept of saturation, as well as the non-detailing of the evidence that points to the achievement of the degree of saturation; and, in some cases, limited information appears on the point at which saturation occurred, as achieved or not, based on the statement about what was observed ${ }^{(10)}$. Thus, the relevance and justification of the present study are strengthened by the need to support researchers on the methodological path to reach the degree of saturation by applying the GT.

It is noteworthy that theoretical sampling is considered a registered trademark of GT, which works with a particular type of sampling or selection of research participants, not formed a priori, but in the course of the research, based on constructs theoretical issues that emerge from the data collected and analyzed ${ }^{(2-3)}$. It intends to deepen the understanding of the phenomenon, adjusted to the theoretical sensitivity of the researcher.

Thus, the question is: How to achieve the degree of saturation by applying GT?

\section{OBJECTIVES}

To achieve the degree of saturation in study that applied the grounded theory.

\section{METHODS}

\section{Ethical aspects}

In compliance with the ethical principles of research involving human beings, the research project was approved by the Research Ethics Committee (CEP) of the Anna Nery School of Nursing, Federal University of Rio de Janeiro, in April 2018. Participants signed the Informed Consent Form.

\section{Study type}

Descriptive, exploratory, qualitative research, which used the Consolidated Criteria for Reporting Qualitative Research (COREQ) 
checklist to ensure methodological validity. The GT was applied, which proposes to maintain and preserve a strong rooting of the concepts and theories constructed with empirical data ${ }^{(3)}$.

\section{Study scenario}

The study was developed in four Family Health Units, located in the urban area of the city of Porto Velho, Rondônia, Brazil.

\section{Data collection and organization}

Data collection took place between June 2018 and May 2019. The saturation component, which is developed through theoretical sampling and the construction of sample groups ${ }^{(13-14)}$, was described by the data collection and analysis process by semi-structured interview with 30 professionals, comprising four sample groups (Chart 1).

Following the assumptions of theoretical sampling, the composition of new sample groups was conducted, according to the requirements of the data itself, through the construction of hypotheses or theoretical constructs. The conduction of the interviews in the different sample groups took place simultaneously, and the circularity of the method was also considered in the extensive progression of the sample, through the analysis of the data, in a dynamic process of comparison between incidents and properties of the conceptual codes, as well as between conceptual codes, categories and subcategories. In addition to the initial interview question, circular questions were asked to deepen the understanding of the phenomenon investigated and to reach the degree of saturation.

The selection of participants, both in terms of their number and the characteristics of their professional profile, took place with the use of an extensive and progressive analytical process, conducted by the demanding work of theoretical conceptualization.

It is noteworthy that the codification process in the GT emanates from the balance between the objective, what the data brings, and the subjective, the understanding stimulated based on the researcher's experience, on the theoretical sensitivity involving the capacity for abstraction that arises from the hermeneutics made possible through interviews and observation in the analytical path.

To show the degree of development of conceptual codes and theoretical categories, as well as the emergence of new codes and the way they were being used, a chart was built in Microsoft ${ }^{\circ}$ Word 97-2003 with the information: interview number; number of preliminary codes generated; number of preliminary codes used; number of new conceptual codes; number of new subcategories or categories; modifications to previously prepared categories or subcategories. The feeding of this chart also relied on information from theoretical memos that pointed to evidence of reaching the degree of saturation.

The layout of the interviews in Arabic number was organized by order of performance, regardless of the sample group of which the participant was part, in order to show how and when new information no longer represented new properties or dimensions to the categories.

\section{Data analysis}

The cyclical process between data collection and analysis allowed the elaboration of concepts, which were configured in the three levels of data coding, namely: open coding (concept assignment - preliminary codes that bring an idea of the action based on the word analysis the word, line by line or paragraph by paragraph of the raw data); axial coding (grouping by similarity of preliminary codes into conceptual codes and formation of categories based on an inductive and deductive process that seeks to find explanations for the phenomenon); and integration (final stage of development and organization of the theory using the analysis tool "coding paradigm", which considers the conditions, actions-interactions and consequences related to the investigated phenomenon) ${ }^{(3)}$.

To illustrate the process of abstraction and density of the theory that was developed based on the data, the contribution of each participant in the structuring of the categories and subcategories was highlighted, considering their properties and dimensions.

Chart 1 - Sample groups, hypotheses, and initial question of the interview

\begin{tabular}{|c|c|c|}
\hline Sample groups & Hypotheses & Initial question of the interview \\
\hline $\begin{array}{l}1^{\text {st }} \text { group: } 14 \text { professionals who } \\
\text { worked in the Family Health } \\
\text { Strategy teams }\end{array}$ & $\begin{array}{l}\text { In compliance with the object of study (The meaning } \\
\text { attributed by health professionals who work in the } \\
\text { Family Health Strategy on Permanent Education in } \\
\text { Health, from the perspective of work management) }\end{array}$ & $\begin{array}{l}\text { What meaning do you attribute to Permanent } \\
\text { Health Education? }\end{array}$ \\
\hline $\begin{array}{l}2^{\text {nd }} \text { group: six health management } \\
\text { professionals in the Municipality }\end{array}$ & $\begin{array}{l}\text { Assigning responsibility for Permanent Health } \\
\text { Education practices to the initiative of health } \\
\text { professionals and managers }\end{array}$ & $\begin{array}{l}\text { Comment on the statement: the responsibility for } \\
\text { the practices of Permanent Education in Health } \\
\text { should be attributed to health professionals and } \\
\text { health managers and should therefore be the } \\
\text { initiative of both parties. }\end{array}$ \\
\hline $\begin{array}{l}3^{\text {rd }} \text { group: six managers of Primary } \\
\text { Health Care Units }\end{array}$ & $\begin{array}{l}\text { Assigning responsibility for Permanent Health } \\
\text { Education practices to the initiative of health } \\
\text { professionals, managers, and managers of health units }\end{array}$ & $\begin{array}{l}\text { What is the role of health unit managers in relation } \\
\text { to Permanent Health Education in the Family Health } \\
\text { Strategy? }\end{array}$ \\
\hline $\begin{array}{l}4^{\text {th }} \text { group: four professionals who } \\
\text { worked at the Management Center } \\
\text { for Permanent Education in Health of } \\
\text { the Municipal Health Secretariat }\end{array}$ & $\begin{array}{l}\text { Assigning the responsibility for Permanent Health } \\
\text { Education in the Primary Care department to } \\
\text { the Management Center for Permanent Health } \\
\text { Education }\end{array}$ & $\begin{array}{l}\text { Comment on the performance of the Center for } \\
\text { Management of Permanent Education in Health in } \\
\text { the process of permanent education of managers, } \\
\text { unit managers and Family Health Strategy teams. }\end{array}$ \\
\hline
\end{tabular}




\section{RESULTS}

Following the full conceptual description, in the line-by-line analysis of the raw data from the 30 interviews, in the open coding stage, 2,239 preliminary codes were generated, of which 1,747 were used in the construction of the conceptual codes, as they represent the excerpts of the analytically relevant interviews for the fulfillment of the research goals and objectives.

The grouping of preliminary codes for similarity in axial coding gave rise to 17 conceptual codes, based on the reflection stimulated by the questions: Why? In what way? At where? When? It is like? The search for such answers, through reflection in the analytical process, guided the achievement of the degree of saturation for the development of the theory, using interrelation of the concepts in categories, in an inductive and deductive process, related to the means in which the categories were manifested.

In each interview carried out, in addition to the process of organizing and analyzing the data in the coding, hypotheses were evidenced to support the paths to be taken by the researcher and the decision making about the theoretical sampling. In Chart
2 , it is observed that, as of the $12^{\text {th }}$ interview, new conceptual codes or categories and subcategories were no longer generated. However, it is evident that the content of the $22^{\text {nd }}$ interview still contributed to deepen the knowledge about the properties and dimensions emerging from the data with a view to strengthening the concepts, adding an increasing instance to the same code, but without a new category.

The visual layout as a way to operationalize the use of the component related to theoretical sampling and construction of sample groups, as well as the number of new codes, could guide the researcher in identifying the extent of saturation necessary to develop the conceptual body of the categories, that subsidized the construction of the substantive theory.

Considering the outline of the theoretical sample and the number of study participants (Chart 2), these were fundamental aspects to achieve saturation: the indicator of the amount of preliminary codes generated and used in each interview, the development of conceptual codes and the observation in the process of collection and analysis of data on the extent to which such codes generated new categories/subcategories or indicated changes to existing ones.

Chart 2 - Number of preliminary codes generated and used, conceptual codes, subcategories and categories generated and/or modified, per interview

\begin{tabular}{|c|c|c|c|c|c|}
\hline Interview & $\begin{array}{l}\text { No. of preliminary } \\
\text { codes generated }\end{array}$ & $\begin{array}{l}\text { No. of preliminary } \\
\text { codes used }\end{array}$ & $\begin{array}{c}\text { No. of new } \\
\text { conceptual codes }\end{array}$ & $\begin{array}{l}\text { No. new categories/ } \\
\text { subcategories }\end{array}$ & $\begin{array}{l}\text { Modification in categories/ } \\
\text { subcategories }\end{array}$ \\
\hline 1 & 54 & 49 & 7 & $5 / 2$ & Yes \\
\hline 2 & 80 & 71 & 6 & $6 / 1$ & Yes \\
\hline 3 & 55 & 45 & 0 & 0 & No \\
\hline 4 & 44 & 44 & 1 & $1 / 0$ & Yes \\
\hline 5 & 49 & 47 & 1 & 0 & No \\
\hline 6 & 39 & 34 & 0 & 0 & Yes \\
\hline 7 & 57 & 44 & 1 & $1 / 0$ & Yes \\
\hline 8 & 26 & 20 & 0 & 0 & No \\
\hline 9 & 28 & 19 & 0 & 0 & No \\
\hline 10 & 43 & 33 & 0 & 0 & No \\
\hline 11 & 59 & 51 & 1 & 0 & Yes \\
\hline 12 & 28 & 18 & 0 & 0 & No \\
\hline 13 & 49 & 39 & 0 & 0 & Yes \\
\hline 14 & 18 & 15 & 0 & 0 & No \\
\hline 15 & 146 & 136 & 0 & 0 & Yes \\
\hline 16 & 168 & 126 & 0 & 0 & No \\
\hline 17 & 39 & 37 & 0 & 0 & No \\
\hline 18 & 23 & 12 & 0 & 0 & No \\
\hline 19 & 41 & 35 & 0 & 0 & No \\
\hline 20 & 26 & 17 & 0 & 0 & No \\
\hline 21 & 80 & 68 & 0 & 0 & No \\
\hline 22 & 67 & 54 & 0 & 0 & Yes \\
\hline 23 & 175 & 172 & 0 & 0 & No \\
\hline 24 & 122 & 82 & 0 & 0 & No \\
\hline 25 & 60 & 58 & 0 & 0 & No \\
\hline 26 & 156 & 61 & 0 & 0 & No \\
\hline 27 & 99 & 88 & 0 & 0 & No \\
\hline 28 & 104 & 40 & 0 & 0 & No \\
\hline 29 & 150 & 93 & 0 & 0 & No \\
\hline 30 & 154 & 139 & 0 & 0 & No \\
\hline Total & 2,239 & 1.747 & 17 & 13 & \\
\hline
\end{tabular}


The development of the structural elements of the theory was based on data generated by the initial question of the interview, by the circular questions to deepen what qualified the phenomenon and by the experience of the researcher in the area of expertise of the study, which refers to the theoretical sensitivity. The density of the data generated in the first and second interviews, as observed in the number of new conceptual codes, categories, and subcategories, guided the theoretical sampling aimed at reaching the degree of saturation, stating, in this process, that theoretical saturation was the main guiding principle for deepen the concepts.

Despite the joint incorporation of elements of thematic inductive saturation, characterizing the hybrid saturation, it is emphasized that the reach of saturation based only on the evidence of the number of codes can result in the interpretive inconsistency that distances the data and the researcher from the real understanding about the properties and constituent dimensions of the codes, as well as the interactions between these codes for the identification and strengthening of concepts.

From this conjuncture, we can see the fact that, for research with GT, similar to what happens with other qualitative investigations, the properties of the data matter more than the number of them/the research participants.

Chart 3 shows the records made during the research, providing clarity regarding the exact moment of data collection and analysis in which the categories or subcategories emerged or were modified.

Chart 3 - Record of the development of categories and subcategories according to the contribution of each interview

\begin{tabular}{|c|c|c|}
\hline Interview & Development of categories and subcategories & Contributions \\
\hline \multirow{7}{*}{01} & Category 1: Signifying PHE ${ }^{*}$ and its conditioning factors in the context of primary health care & 1 category \\
\hline & Subcategory 1.1: Understanding PHE as a dialogical teaching-learning process & 1 subcategory \\
\hline & Subcategory 1.4: Linking PHE to health education & 1 subcategory \\
\hline & $\begin{array}{l}\text { Subcategory 1.5: Pointing out the conditioning factors of PHE in the context of primary health care to multi- } \\
\text { professional teamwork }\end{array}$ & 1 subcategory \\
\hline & Subcategory 1.7: Considering that $\mathrm{PHE}$ is not yet part of the work routine & 1 subcategory \\
\hline & $\begin{array}{l}\text { Category 3: Organizing the work process of the assistance and management teams, according to assumptions of } \\
\text { situational strategic planning }\end{array}$ & 1 category \\
\hline & Subcategory 3.1: Applying the Family Health Strategy guidelines according to health planning assumptions & 1 subcategory \\
\hline \multirow{8}{*}{02} & Subcategory 1.2: Valuing PHE & 1 subcategory \\
\hline & Subcategory 1.3: Relating PHE to continuing education & 1 subcategory \\
\hline & $\begin{array}{l}\text { Subcategory 1.5: Components: Conditioning to the political-economic context; conditioning the availability of } \\
\text { resources (physical space) }\end{array}$ & $\begin{array}{l}2 \text { components da } \\
\text { subcategory }\end{array}$ \\
\hline & $\begin{array}{l}\text { Subcategory 1.6: Relating the best PHE development to the characteristics of each professional on the team, such } \\
\text { as the leadership profile }\end{array}$ & 1 subcategory \\
\hline & Category 2: Referring plans and actions to enable PHE & 1 category \\
\hline & Subcategory 2.4: Reporting PHE practices & 1 subcategory \\
\hline & Subcategory 2.2: Assigning responsibility for PHE practices to the initiative of care and management professionals & 1 subcategory \\
\hline & Subcategory 3.2: Seeking to qualify assistance & 1 subcategory \\
\hline \multirow{2}{*}{04} & Subcategory 2.3: Outlining management initiatives in the context of PHE & 1 subcategory \\
\hline & Subcategory 3.2: Seeking to organize assistance & Modification \\
\hline 06 & $\begin{array}{l}\text { Subcategory 1.6: Relating the best PHE development to the characteristics of each professional on the team, such } \\
\text { as the leadership profile and the professional category }\end{array}$ & Subcategory addition \\
\hline \multirow{3}{*}{07} & Subcategory 1.5 : Conditioning the integration of care and management professionals & $\begin{array}{l}1 \text { component of } \\
\text { subcategory }\end{array}$ \\
\hline & Subcategory 2.1: Managing PHE & 1 subcategory \\
\hline & Subcategory 2.2: Higher education institutions & Subcategory addition \\
\hline 11 & $\begin{array}{l}\text { Subcategory 2.2: Assigning responsibility for PHE practices to the initiative of healthcare professionals, } \\
\text { management and higher education institutions }\end{array}$ & Subcategory addition \\
\hline 13 & $\begin{array}{l}\text { Subcategory 1.6: Relating the best PHE development to the characteristics of each professional on the team, such } \\
\text { as the leadership profile and the position held in management }\end{array}$ & Subcategory addition \\
\hline
\end{tabular}




\begin{tabular}{|c|l|l|}
\hline Interview & Development of categories and subcategories & Contributions \\
\hline 15 & Subcategory 2.1: Building PHE & Modification \\
\hline 22 & Subcategory 1.5: Conditional on the availability of resources (human resources) & Subcategory addition \\
\hline
\end{tabular}

*PHE - Permanent Health Education.

It can be seen that, just as not all the preliminary codes were used, not all the interviews composed constructs to deepen the concepts and propositions/premises.

The categories and subcategories were analyzed in a refined, continuous, and compared way, allowing the integration and theoretical scope of the concepts. Category 1 was represented by seven subcategories; Category 2, for four subcategories; and Category 3, by two subcategories. The integration of the three with the application of the paradigm unveiled the central phenomenon, which, in a few words, brings to light a concept considered the main theme of the study. Thus, the substantive theory, organized according to the elements of the paradigm, was conceptually structured by categories and subcategories that approached the reality investigated with clarity and coherence.

\section{DISCUSSION}

Studies that focus on the method itself, discussing the information from the methodological path in depth, valuing its use with the rigor required by qualitative research and by GT, may collaborate with greater clarity in relation to the support given by the method to scientific research ${ }^{(1,10-11)}$.

GT's rigor lies in the wealth of details related to procedures, instruments and techniques, which seek to guide the development of research in an articulated manner to the proposed objectives, qualifying and validating the research by giving them the theoretical and methodological rigor required in the construction of scientific knowledge ${ }^{(2)}$.

It is a methodological reference considered young, with significant evolution, represented by the diversity of methodological aspects that express ontological and epistemological views of its authors, in their contexts, related to the method. Due to this methodological dynamism, it still needs conceptual and operational alignments that elucidate its "correct" use dynamics, although it maintains in essence the postulates of Glaser and Strauss ${ }^{(15)}$.

Several authors point to the need for further studies to analyze how GT has been used in health and nursing research, in order to collaborate with the continuous development of the method. Thus, each new experience of using this framework is valued as a renewed possibility of learning in relation to the method, to assist in conducting research that chooses to use it $^{(1,4,16)}$.

The presentation of Chart 1 meets both the importance of transparency regarding the constitution of sample groups in the GT, following the methodological rigor, as well as the role that this stage of the method plays regarding the saturation component, through sampling. theoretical framework, promoting breadth in terms of the context in which the research was carried out ${ }^{(2-3)}$.

Furthermore, with the new developments in science and scientific production, with open science and, consequently, the opening of raw data to the entire scientific community, transparency about the analytical process is essential for scientific development and integrity. Therefore, qualitative research must increasingly pay attention to the importance of methodological coherence that allows clarity about data saturation and epistemological progress resulting from science criteria.

In GT, theoretical saturation occurs at the moment when the theoretical sampling constituted is sufficient to support the developed theory, based on the empirical data of the research. The saturation of theoretical categories allows data collection to be interrupted when new information does not alter the understanding of the investigated phenomenon. The lack of description of the phases and peculiarities related to the method, including the lack of explanation of the way in which the theoretical sampling and the degree of saturation were achieved, make it difficult to understand how the understanding of the phenomenon was contemplated in its conceptual depth ${ }^{(1-3)}$.

In the diversity of the analyzed variables - methodological aspect of the GT, theoretical framework, data collection technique, analytical resources such as description of the construction of the sample groups, simultaneity between data collection and analysis, stages of the coding process, use of memos and diagrams, theory validation -, recent studies related to GT point a gap in the analysis of the issue specifically related to the degree of saturation ${ }^{(9,16)}$

In a study whose objective was to analyze the use of GT as a methodological reference in scientific articles published in Brazilian journals in the field of nursing, the reach of theoretical saturation was specified in most studies $(53.1 \% ; n=26)$, with the remaining $46.9 \%(n=23)$ did not even specify such a methodological procedure (17). The latter only highlighted the particularities that differ from the concept of data saturation in qualitative research, when compared to the other conceptual models employed in $\mathrm{GT}^{(3)}$.

An analysis of studies regarding GT in the Brazilian scientific production of nursing found that, of 12 selected studies, only $5(41.7 \%)$ addressed in the process of collecting and analyzing data citation regarding saturation, and only 1 made mention of the expression of its meaning ${ }^{(1)}$.

The lack of an instrument that directs the use of the method by nursing researchers in Brazil may perhaps explain the failure to contemplate the main methodological aspects of GT in articles or published studies ${ }^{(17)}$.

Recognizing the importance of the saturation component in the data collection interruption process, some essential elements were considered, namely: the circularity of the method between data collection and analysis inherent to the GT; the triangulation of data collection techniques, as in the case of semi-structured interviews and non-participant observation; the registration and immersion in the data, which can count on the support of a software to organize theirs; theoretical and analytical approach about the meanings of the generated codes; and identification of saturation based on the ability of the results to present some degree of generalization. It is noteworthy that the analysis 
concomitant with the data collection leads to the codification and development of the theory at an advanced stage of the analysis.

In order to operationalize the methodological path to reach the degree of saturation, the individual depth of each interview is outlined, through circular questions about the investigated phenomenon; generation and grouping of the codes that will give rise to the concepts (conceptual codes, categories and subcategories); and depth at the conceptual level, which leads to theoretical sampling, abstraction and density of theory. It stands out as an important tool the construction of pictures or other visual and didactic resources that allow organizing the themes or categories, identifying elements related to their origin and construction.

When presenting the records in Charts 2 and 3 , elements of the conceptual model of theoretical saturation were used, just as there was an approximation of the conceptual model of inductive thematic saturation, characterizing hybrid saturation, which combines two or more conceptual models ${ }^{(10)}$. The inductive thematic saturation resulted from the analysis of the emergence of new codes that could give rise to new themes, that is, to verify if the emergence of new preliminary codes was generating new themes or conceptual codes, which, in turn, originated new subcategories and/or categories ${ }^{(10)}$.

It would be a significant mistake as a researcher, when using the GT as a methodological reference, not to take into account the concept of theoretical saturation, since its origin is precisely linked to the GT. Theoretical saturation adopts as a criterion for additional data collection the development of categories and, consequently, of a theory throughout the data analysis process, this perspective being linked to the idea of saturation by theoretical sampling ${ }^{(10)}$.

It is worth noting that the conceptual model of data saturation distances itself from the studies that apply the GT. In data saturation, there is a redundancy of them, that is, the new ones repeat what had already been expressed in previous data, distancing themselves from the GT because there is not necessarily a link of the new data to a theory and to the process of formal analysis of the data, the researcher being able to decide on the completion of the collection even before the analysis stage ${ }^{(10)}$.

As stated, data saturation is not formally related to their analysis process, having as main focus only the data collected ${ }^{(10)}$. In the GT, the collection and analysis process, according to the rigor recommended by the method, takes place concurrently, and the researcher should only proceed to the next interview after completing the entire analysis process for each interview carried out ${ }^{(2-3)}$.

Regarding the research objectives, it is up to the researcher to be vigilant at the time when they were met, this being a form of certification that the degree of saturation has been reached. Some clues can be decisive with regard to this issue, varying according to the methodological framework used. In studies with an inductive and deductive approach, such as GT, which propose the development, construction or discovery of a theory, the researcher must be aware of the moment when, in addition to the saturation criteria observed in the different conceptual models, the theory is supported by dense categories and with a degree of breadth that portrays the phenomenon related to the research context ${ }^{(2-3,10)}$.

Glaser and Strauss warn that answering the question about whether or not saturation occurred and at what exact point it happened is a decision of the researcher, who, through a continuous process of data analysis, accumulates information allowing to judge that the degree of saturation has been reached, not the point of saturation. This is because it must be clear that the saturation is identified not at a specific moment in the research, but over the course of a process ${ }^{(12)}$.

Furthermore, the generated theory has the possibility of being modified by means of new elements that can emerge at any moment of the research, be it on the last day of data collection, during the review of the theory or the theoretical matrix, or even after the publication of a final report ${ }^{(11)}$. Thus, it is appropriate to relativize the very pure term of saturation, which, based on the declaration of the saturation range based on what is observed and what is not observed, should be minimally understood as a matter of degree of saturation ${ }^{(10)}$.

In the GT, considering the diversity of paths and possibilities to be followed, especially linked to the concept of theoretical sampling, it may be more appropriate not to think exclusively about the completeness and state of the empirical data, but rather in the conceptual depth as sufficient or not for the development of the theory, through codes that are sufficient in relation to the emerging thematic categories ${ }^{(10)}$.

Based on the continuous and cumulative judgment inherent in saturation, as a process that may never be concluded, at GT, based on this example that worked mainly on saturation through theoretical sampling to reach the highest degree of development of the conceptual codes already identified, it should be noted that, in some situations, it may not be possible to cover all potential participants in the same research report, according to their relationship with the investigated phenomenon and questions that may still permeate the properties and dimensions of the concepts developed.

Therefore, the reports need to be transparent about the applied concept and operationalization of saturation, this being the gold standard of qualitative research. Still, they should clearly point out referrals for new studies, in search of complementarity between the knowledge in constant production, based on the theoretical and analytical approach ${ }^{(10)}$.

\section{Study limitations}

Recognizing that the form of systematization of information presented in this study is not something unique, in the sense of explaining the way in which the saturation component was treated in a research, it is recommended to carry out further studies, which may contribute with reflections on of this methodological component in the GT and in other qualitative research.

Despite the investment to incorporate the elements of more than one conceptual type of saturation, the study presents a risk of inconsistency when considering saturation as completeness. Hence, the importance of epistemological surveillance is highlighted to consider the conceptual depth and knowledge in constant production.

\section{Contributions to the field of nursing and health}

It should be noted that conceptual saturation models, especially theoretical saturation, as a criterion for discontinuing data collection in the GT, have been proposed in other qualitative research methodological designs. Because saturation has little distinction between the different scientific methods that use it, there is the potential to contribute to studies other than those that apply GT, so that they can 
describe in detail the path taken along the research, demonstrating evidence regarding to the process of data collection and analysis and its relationship with reaching the degree of saturation.

\section{FINAL CONSIDERATIONS}

The degree of saturation was achieved in this research by applying the conceptual models of theoretical saturation and thematic inductive saturation, in a hybrid way. Theoretical saturation was the main guideline to deepen the concepts, since it works with saturation through theoretical sampling in order to develop the conceptual codes already identified. Thus, this was the most decisive move towards discontinuing data collection, confirmed by evidence of the number of codes generated.
The charts, as one of the possible schematic resources in the GT, facilitated the understanding of complex situations and processes, such as monitoring and comparing the subcategories and categories throughout the extensive and elaborated analysis of the data. A workflow made explicit by means of schemes that demonstrate the relationship between the various concepts favors the systematic interrelationship between them.

Based on the above, the final research report presented evidence of how the degree of saturation was achieved. Saturation was operationalized as a methodological principle that gives validity to the science criteria based on qualitative research, giving clarity to the researcher in the answers to the research questions, reaching the proposed objectives and developing the conceptual body of the categories that supported the substantive theory.

\section{REFERENCES}

1. Gomes IM, Hermann AP, Wolff LDG, Peres AM, Lacerda MR. Grounded theory in nursing: integrative review. Rev Enferm UFPE. 2015;9(Suppl-1):466-74. https://doi.org/10.5205/1981-8963-v9i1a10360p466-474-2015

2. Tarozzi M. O que é grounded theory?: metodologia da pesquisa e de teoria fundamentada nos dados. Petrópolis: Vozes; 2011.

3. Corbin J, Strauss A. Basics of qualitative research: techniques and procedures for developing grounded theory. 4th ed. Thousand Oaks, CA: SAGE; 2015.

4. Santos JLG, Erdmann AL, Sousa FGM, Lanzoni GMM, Melo ALSF, Leite JL. Methodological perspectives in the use of grounded theory in nursing and health research. Esc Anna Nery. 2016;20(3):e20160056. https://doi.org/10.5935/1414-8145.20160056

5. Roman DJ, Osinski M, Erdmann RH. The construction process of grounded theory in administration: El proceso de construcción de la grounded theory en administración. Contaduria Adm. 2017;62(3):985-1000. https://doi.org/10.1016/j.cya.2016.06.012

6. Andrews T, Mariano GJS, Santos JLG, Koerber-Timmons K, Silva FH. The methodology of classic grounded theory: considerations on its application in nursing research. Texto Contexto Enferm. 2017;26(4):e1560017. https://doi.org/10.1590/0104-070720170001560017

7. Solano LC, Miranda FAN, Enders BC, Sousa FGM. By avenue: dialoging about grounded theory. Rev Enferm UERJ. 2018;26:e28047. https:// doi.org/10.12957/reuerj.2018.28047

8. Juanillo-Maluenda H. Posicionamiento del investigador de enfermería en la utilización de la teoría fundamentada constructivista. Enferm Univ. 2019;16(2):205-15. https://doi.org/10.22201/eneo.23958421e.2019.2.638

9. Silva GWS, Enders BC, Sousa FGM, Sena JF, Santos RC, Silva AB. Grounded theory in theses and dissertations of brazilian nursing. Texto Contexto Enferm. 2018;27(4):e3870017. https://doi.org/10.1590/0104-07072018003870017

10. Saunders B, Sim J, Kingstone T, Baker S, Waterfield J, Bartlam B, et al. Saturation in qualitative research: exploring its conceptualization and operationalization. Qual Quant. 2018;52(4):1893-907. https://doi.org/10.1007/s11135-017-0574-8

11. Nascimento LCN, Souza TV, Oliveira ICS, Moraes JRMM, Aguiar RCB, Silva LF. Theoretical saturation in qualitative research: an experience report in interview with schoolchildren. Rev Bras Enferm. 2018;71(1):228-33. https://doi.org/10.1590/0034-7167-2016-0616

12. Glaser, BG, Strauss, AL. The discovery of grounded theory: strategies for qualitative research. New Brunswick: Aldine; 1967.

13. Cunha KS, Andrade SR, Erdmann AL. University management nurse: a grounded theory. Rev Latino-Am Enfermagem. 2018;26:e2980. https://doi.org/10.1590/1518-8345.2199.2980

14. Carneiro JB, Gomes NP, Campos LM, Silva AF, Cunha KS, Costa DMSC. Understanding marital violence: a study in grounded theory. Rev Latino-Am Enfermagem. 2019;27:e3185. https://doi.org/10.1590/1518-8345.3116.3185

15. Ralph N, Birks M, Chapman Y. The methodological dynamism of grounded theory. Int J Qual Methods. 2015;14(4):1-6. https://doi. org/10.1177/1609406915611576

16. Santos JLG, Cunha KS, Adamy EK, Backes MTS, Leite JL, Sousa FGM. Data analysis: comparison between the different methodological perspectives of the grounded theory. Rev Esc Enferm USP. 2018;52:e03303. https://doi.org/10.1590/S1980-220X2017021803303

17. Peiter CC, Santos JLG, Kahl C, Copelli FHS, Cunha KS, Lacerda MR. Grounded Theory: use in scientific articles published in Brazilian nursing journals with Qualis a classification. Texto Contexto Enferm. 2020;29:e20180177. https://doi.org/10.1590/1980-265X-TCE-2018-0177 